
media

\title{
Asimina Michailidou
}

University of Oslo, Norway

\begin{abstract}
This is the post-referee version of the article. For access to the published version and in order to quote this work, please use the following information:

Michailidou, Asimina (2015) 'The role of the public in shaping EU contestation: Euroscepticism and online news media', International Political Science Review vol. 36 no. 3 324-336, doi: 10.1177/0192512115577230, published: June 2015; Publisher: SAGE
\end{abstract}

\begin{abstract}
The participation of the public in framing and debating the news has added a new layer in the making of European Union contestation and the European public sphere, traditionally driven by journalists and political elites. Drawing on news coverage of the ongoing Eurocrisis (2010-2013) and the 2009 European Parliament elections, this article examines the structure and content of European Union contestation in mainstream online news media over time and across several European Union member states. The cross-national patterns that emerge from this analysis strongly suggest that, despite the differences between the observed online news spheres, the European Union is rather uniformly contested: national politics firmly remain the key defining 'frame'; Eurosceptic claims are very much focused on the present rather than the future; and contributors often appeal to the public's emotions rather than reason. Furthermore, the Eurocrisis appears to have consolidated European Union contestation on the more substantial issues of power, solidarity and accountability.
\end{abstract}

\section{Keywords}

Euroscepticism, public sphere, online news media, EU contestation 


\section{Introduction}

Five years after the Eurocrisis erupted in the heart of the European Union (EU), Euroscepticism has been steadily gaining momentum across member states. The 2014 European Parliament (EP) elections have produced a more Eurosceptic cohort of MEPs than ever before: approximately a third of elected representatives identify themselves as Eurosceptic or anti-European. Such is the speed and strength with which Euroscepticism is entering mainstream politics that the pro-European think tank 'European Council on Foreign Relations' recently likened Euroscepticism to a virus that 'has now spread across the continent' (Torreblanca et al., 2013: 1).

A core feature of party politics in several EU member states, Euroscepticism is also a key component of public demands for EU legitimacy. In other words, Euroscepticism is very much a part of the politicization of the $E U,{ }^{1}$ whereby the design of representative institutions and procedures of EU decision-making have become part of public and media demands for democratic legitimacy. In this context, the politicization of the EU polity can be approached as 'a process of public mediation and contestation through which formalized representative relationships have been conducive to but also constrained by mass media attention' (Michailidou and Trenz, 2013: 261). Online media, particularly social media, appear instrumental in the amplification of EU contestation and popular discontent. For several of the current MEPs for example and the national political parties they represent, online news and social media have played a catalytic role in their becoming popular and remaining in the public eye until the crucial date of the EP elections; a case in point is the Italian Beppe Grillo and his Five Star Movement.

Yet despite the crucial role that the media and public actors play in shaping EU politicization, empirical research on the EU contestation mechanisms at work in the public sphere remains thus far limited. This is particularly the case with the ongoing Eurocrisis (Statham and Trenz, 2014), where research has thus far mainly documented the institutional arrangements of EU 'crisis governance' (e.g. Crum and Fossum, 2013; Peters and Randma-Liiv, 2011).

This article has a special focus on the voice of the public in EU contestation. Online media make it possible to map out and analyse not only the journalist-filtered public opinions about the EU polity, but also the unsolicited, spontaneous views of EU citizens, as these appear in social media and commentary forums of online news platforms. Does the increasingly important role of online media in the European public sphere 
bring any new qualities to the EU public opinion-making process? Do citizens' views dynamically enter the European public sphere(s)? Or is the role of online news and social media inflated, with the usual public actors still very much steering public opinion about the EU? Which opinions and perspectives about the EU polity are gaining prevalence in the current social media-driven public sphere and, crucially, does the online media environment offer Euroscepticism ample room to flourish?

A caveat is necessary here: There is no doubt that there is an element of self-selection bias in citizens' comments found online, in that those who opt to post their opinion on social media or a news forum may not necessarily be representative of broader public opinion. Nevertheless, this article - and the wider research that underpins it - neither claims that online EU contestation is representative of public opinion, nor indeed tries to prove such a correlation. Rather, there is a two-fold aim: first to show how EU contestation, once primarily the topic of elite academic debates or marginal political or civic groups, unfolds in the broader public sphere; and second, to show how the presence of citizens' comments contributes to the shaping of such public contestation.

This mapping of EU contestation in the EU online sphere requires the conceptual, analytical and operational 'marriage' of an ambivalent term (Euroscepticism) with a public environment that is characterized by ephemerality, anonymity and vast amounts of information (online news spheres). In the remainder of the article, the methodological and conceptual challenges that arise from this 'marriage' are discussed first, before quantitative data collected during the 2009 European Parliament elections and a three-year period (2010-2012) of the ongoing Eurocrisis are used to map out the qualities of online EU contestation. ${ }^{2}$ In the concluding section of the article, the empirical findings are discussed in light of the possibilities and limitations that online media present for the establishment of a trans-European online public sphere, as well as the implications such a public sphere would have for EU politics.

\section{EU contestation and online media: the conceptual challenge}

In the study of Euroscepticism there has been a long-standing call for a more accurate method of capturing this elusive concept both quantitatively and qualitatively (Usherwood et al., 2014). In this article, Euroscepticism is understood as part of broader EU politicization and public contestation processes unfolding in the public sphere, rather than as an 'independent' phenomenon (de Wilde et al., 2013). From this perspective, EU polity contestation unfolds along three dimensions: (a) the principle of transnational integration (are we better off doing things together?); (b) the fit of 
current institutional arrangements (is there a justifiable institutional framework that guarantees general compliance with the principle?); and (c) the ideational or material support of the EU project (are there shared goals that drive the process of future integration?) (de Wilde et al. 2014: 4). This leads to the typology of EU polity contestation presented in Table 1 below.

Further drawing on the conceptualization of different economies of worth (Boltanski and Thévenot, 2006), the legitimacy of the EU can be defended or denounced on the basis of claims that (a) European integration increases democracy; (b) European integration serves the purpose of preserving a shared cultural heritage and Europewide shared values; (c) European integration is necessary to cope with modern policy problems or in light of previous commitments; (d) European integration increases economic prosperity through stimulating economic growth and general welfare; or (e) European integration is regarded as protecting Europe from internal and/or external threats of various types (de Wilde et al., 2013).

Without this typology and the accompanying justifications of EU polity worth, several categories of public statements that contest or support one or more of the EU polity dimensions would have to be classified as 'Eurosceptic', be it soft or hard, even though they make demands for quite different European futures. A further advantage of the above classification of EU contestation is that it acknowledges the reality of imperfect public debates. EU contestation, as it unfolds in the media sphere, does not always meet the argumentative strength that this typology ideally predicts, which is where 'diffuse Euroscepticism' comes in (de Wilde et al., 2013; Michailidou et al., 2014). This term captures stand-alone negative evaluations of the institutional set-up or project of integration without specification of preferences regarding the other two dimensions.

\section{EU contestation and online media: the methodological challenge}

Specifying a classification system for EU contestation claims is only part of the challenge: the next step is to operationalize the typology in public debate settings, the boundaries, content and participants of which are constantly changing. How does one define the boundaries of national online news spheres and then successfully shift through the continuous flow of news information in order to pick out instances of EU contestation? The point of departure here is that the online public sphere is not an entirely equal space, due to both inequalities in accessing the online sphere (digital divide) and differences in how individuals experience their online interactions (Michailidou et al., 2014: 74). When defining the online EU public sphere, it thus 
becomes imperative to factor in geography: far from being a unified space, the EU 'web' comprises national webs in different stages of infrastructure development, internet equality and extent to which online communications are embedded in everyday life (Michailidou et al., 2014: 74).

Another way to think of the web - EU or otherwise - is in terms of 'key feature' spheres, such as the blogosphere, the news sphere or the tag sphere. Comparing an issue across spheres - in the case of the data discussed here, the visibility and type of news coverage and public debate for specific EU polity events - allows us to determine those features that make each sphere unique but also to understand how different spheres interact (Michailidou et al., 2014: 75).

Table 1. Typology of EU polity evaluations.

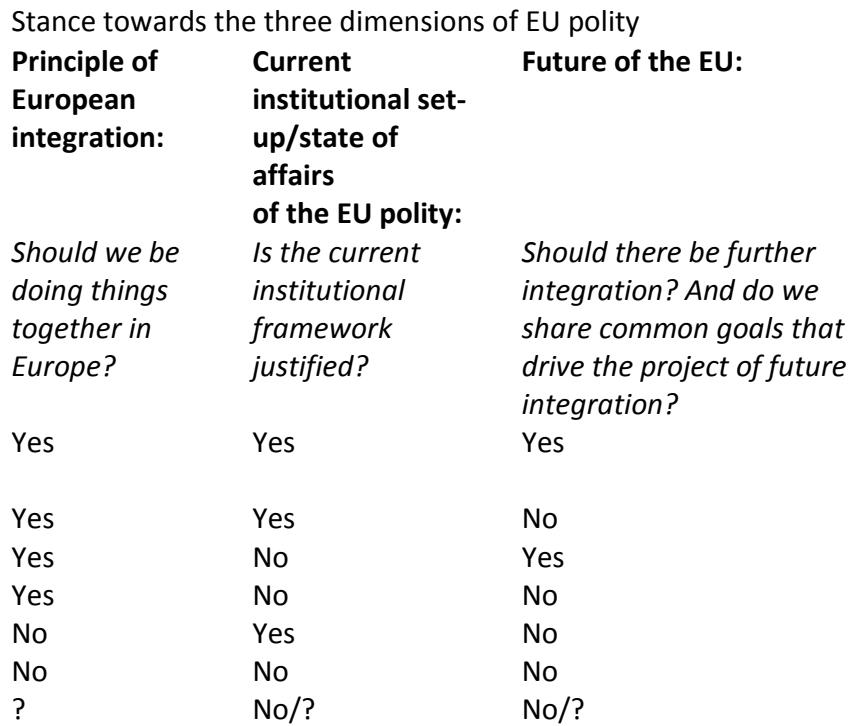

Source: Adapted from De Wilde et al., 2013.
Classification of argument

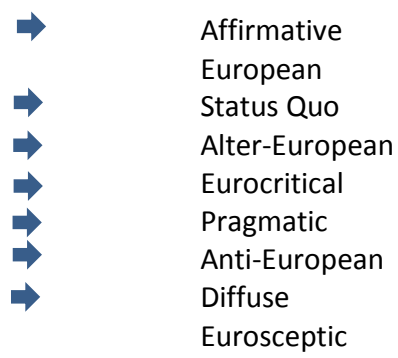

In practical terms, the methodological challenge of demarcating online EU spheres in order to study their profile and interrelation was addressed through a three-step process. First, the number of national and international or foreign news platforms in selected countries was identified, using Alexa web statistics (Alexa Internet, 2014). Secondly, the interconnectedness of national e-news spheres was determined on the basis of media ownership and news platforms present in two or more country online media lists. Thirdly, the study focus was narrowed to the top two or three news providers in each country from which a sample of articles was selected. ${ }^{3}$ 
As Table 2 shows, the majority of the professional news websites selected through this process turned out to be either online versions of well-established, high-circulation newspapers or of popular TV channels, or owned by media conglomerates, which control a host of other audio-visual and print media enterprises. Consequently, we can expect that the reporting and discussion of the EU events on popular news websites mirrors those found in the national offline media systems. The profile of the sampled journalism websites suggests that the online news spheres are, nevertheless, fairly balanced in terms of the type of journalism available. Quality and 'mid-range' tabloid media outlets ${ }^{4}$ are equally popular and thus represented in the sample on almost equal measure, even though the type of journalism offered by an online media outlet was not part of the sample selection criteria.

In the case of the 2009 EP elections, 4815 articles (threads) were collected. From these, 638 articles were selected for coding, following a stratified sampling strategy (stratification by website and time period during which an article appeared online; Michailidou et al., 2014). In the case of the 2010-2012 Eurocrisis dataset, the focus was on news coverage of three specific Eurocrisis events, namely the agreement on Greece's first loan ('bail-out') and establishment of the European Financial Stability Facility (EFSF) in May 2010; the 2011 announcement by then-Prime Minister of Greece,

Table 2. List of news websites and political blogs selected for mapping online Euroscepticism in the period 2009-2012.

\begin{tabular}{|c|c|c|c|}
\hline \multirow[t]{2}{*}{ Country } & \multicolumn{2}{|c|}{ Professional journalism news websites } & \multirow{2}{*}{$\begin{array}{l}\text { Political blogs } \\
2009\end{array}$} \\
\hline & 2009 & 2010-2012 & \\
\hline AT & $\begin{array}{l}\text { derstandard.at } \\
\text { krone.at }\end{array}$ & - & $\begin{array}{l}\text { erstaunlich.at } \\
\text { rigardi.org }\end{array}$ \\
\hline $\mathrm{Be}$ & $\begin{array}{l}\text { lesoir.be } \\
\text { rtl.be } \\
\text { levif.be }\end{array}$ & - & blogs.politique.eu.org \\
\hline$C Z$ & $\begin{array}{l}\text { novinky.cz } \\
\text { aktualne.cz } \\
\text { lidovky.cz }\end{array}$ & - & $\begin{array}{l}\text { blog.idnes.cz } \\
\text { blog.inned.cz }\end{array}$ \\
\hline $\mathrm{DE}$ & $\begin{array}{l}\text { spiegel.de } \\
\text { bild.de } \\
\text { sueddeutsche.de }\end{array}$ & $\begin{array}{l}\text { spiegel.de } \\
\text { bild.de }\end{array}$ & $\begin{array}{l}\text { bildblog.de } \\
\text { pi-news.net/ }\end{array}$ \\
\hline $\mathrm{EL}^{5}$ & $\begin{array}{l}\text { ethnos.gr } \\
\text { tanea.gr } \\
\text { skai.gr }\end{array}$ & $\begin{array}{l}\text { zougla.gr } \\
\text { protothema.gr }\end{array}$ & $\begin{array}{l}\text { press-gr.blogspot.gr } \\
\text { nonews-news.blogspot.com }\end{array}$ \\
\hline ES & - & $\begin{array}{l}\text { elpais.com } \\
\text { elmundo.es }\end{array}$ & not included \\
\hline $\mathrm{FI}$ & $\begin{array}{l}\text { iltalehti.fi } \\
\text { iltasanomat.fi } \\
\text { hs.fi }\end{array}$ & - & $\begin{array}{l}\text { kasvi.org } \\
\text { soininvaara.fi }\end{array}$ \\
\hline
\end{tabular}




\begin{tabular}{|c|c|c|c|}
\hline FR & $\begin{array}{l}\text { lefigaro.fr } \\
\text { lemonde.fr } \\
\text { tempsreel.nouvelobs.com }\end{array}$ & $\begin{array}{l}\text { lefigaro.fr } \\
\text { lemonde.fr }\end{array}$ & $\begin{array}{l}\text { plumedepresse.net } \\
\text { sarkofrance.blogspot.no/ }\end{array}$ \\
\hline HU & $\begin{array}{l}\text { origo.hu } \\
\text { index.hu } \\
\text { figyelo.hu }\end{array}$ & - & $\begin{array}{l}\text { w.blog.hu } \\
\text { reakcio.hu }\end{array}$ \\
\hline $\mathrm{NL}$ & $\begin{array}{l}\text { nu.nl } \\
\text { telegraaf.nl } \\
\text { nos.nl }\end{array}$ & $\begin{array}{l}\text { nu.nl } \\
\text { telegraaf.nl }\end{array}$ & $\begin{array}{l}\text { geenstijl.nl } \\
\text { home.marokko.nl }\end{array}$ \\
\hline NO & - & $\begin{array}{l}\text { dagbladet.no } \\
\text { vg.no }\end{array}$ & - \\
\hline PL & $\begin{array}{l}\text { wyborcza.pl } \\
\text { onet.pl } \\
\text { tvn24.pl }\end{array}$ & - & $\begin{array}{l}\text { palikot.blog.onet.pl } \\
\text { korwin-mikke.blog.onet.pl }\end{array}$ \\
\hline SE & $\begin{array}{l}\text { aftonbladet.se } \\
\text { expressen.se } \\
\text { dn.se }\end{array}$ & $\begin{array}{l}\text { aftonbladet.se } \\
\text { expressen.se }\end{array}$ & $\begin{array}{l}\text { falkvinge.net } \\
\text { politisktinkorekt.wordpress.com }\end{array}$ \\
\hline UK & $\begin{array}{l}\text { bbc.co.uk } \\
\text { guardian.co.uk } \\
\text { dailymail.co.uk }\end{array}$ & $\begin{array}{l}\text { bbc.co.uk } \\
\text { dailymail.co.uk }\end{array}$ & $\begin{array}{l}\text { iaindale.blogspot.com } \\
\text { order-order.com }\end{array}$ \\
\hline
\end{tabular}

George Papandreou, of a referendum on whether Greece would accept a second loan agreement; ${ }^{6}$ and the ratification by the German parliament of the second loan agreement for Greece in December 2012. In total, 1156 online news articles concerning these events were collected and coded (news items sampled up to three days prior to and after the events took place).

Both a quantitative coding technique (2009 EP elections study and 2010-2012 Eurocrisis study) and an interpretative/qualitative approach (2010-2012 Eurocrisis study) were implemented in order to capture not only the statement of preferences made in public but also the way and extent to which these preferences were justified. In addition, the intensity of the relevant debates was measured through the number of comments, Facebook 'likes', retweets and shares in other social media networks (for more details on the coding schedules see Michailidou et al., 2014). ${ }^{7}$

\section{Euroscepticism in context: journalistic coverage of EU issues}

Of the 1794 articles coded in total (638 in 2009 and 1156 for the period 2010-2012), nearly half (863) had a national perspective. By contrast, articles with a European perspective make up just over a third of the data (662 articles). The national perspective ('what does this mean for our country?') is adopted even when the topic of a thread is on the politics, economy or society of another EU member state or of the $\mathrm{EU}$ as a whole. Articles with a national perspective can be broadly classified under two 
categories: those that highlight a 'national interest' angle of specific EU politics events or developments, such as news items in Greek online media covering the establishment of the EFSF mechanism and discussing the implications of this for Greece's economy and fiscal policy; and those that turn specific EU events or developments into a backdrop story for national politics, particularly inter and intraparty conflicts. For example, articles in UK online media, especially on dailymail.co.uk, frequently used Eurocrisis developments as one of many frames to discuss how David Cameron would fare against Tory backbenchers (Michailidou et al. 2014: 107).

Inter- and intra-party negotiations and rivalries of the national political scenes dominate online EU news reporting. For the Eurocrisis e-news coverage, this means that seven out of every 10 articles focused on the 'political elite' aspect of the crisis. By contrast, reporting of Eurocrisis developments in the context of 'people versus national political elites' conflict made up just over seven percent of all articles, climbing up to near nine percent when articles with a theme of conflict between people and EU political elites or banks are added. The economic ramifications of the first and second Greek 'bailouts' as well as of the announced Greek referendum were also thoroughly explored, with nearly one in two articles containing financial details on national debts, on the 'bailout' loan agreements or on the performance of stock markets in relation to these events.

However, given the implications that the Eurocrisis has for democracy at national and EU level (Benz, 2013; Fossum and Menendez, 2014), the near absence of the theme of democracy from online news reporting is unexpected. In the few instances ( 89 articles) when the focus does turn to democracy, reporting remains firmly fixed on party micropolitics or diplomatic sensationalist gossip. Overall, articles with a democracy theme represent on average only six percent of Eurocrisis coverage in each of the seven online public spheres included in the 2010-2012 study, with small variation across countries. One could argue that the nature of the Eurocrisis events justifies perhaps the focus on the economic and political dimensions. When faced with unexpected events that have severe and direct consequences on their lives, EU citizens want to know who is doing what to manage the crisis and with what consequences. The media are quick to provide this information, if not always accurately (Michailidou et al. 2014: 108).

Nevertheless, the same lack of journalistic coverage of the quality of democracy in the $\mathrm{EU}$ is also found in the $2009 \mathrm{EP}$ elections dataset. The day-to-day politics receive plenty of journalist attention, especially the national cohort of government officials, parliamentarians and political party members. Rarely, however, are there any 
reflections in EU news articles about the impact of EU integration on democracy. Yet, this lack of interest by journalists in the democratic implications of the Eurocrisis or the manner in which EP election campaigns are conducted, for example, is in contrast with the manner in which readers of EU news debate the EU polity. As discussed in the following section, readers often use the news commenting forums to express their deep concern with the state of democracy in Europe and the lack of democratic control mechanisms.

Given the journalistic focus on the national perspective of EU events, it is not surprising to find that national politicians feature prominently in EU news coverage, followed closely by politicians of other EU member states. Over half (51 percent) of all the actors mentioned in relation to Eurocrisis news (3381 unique actors recorded in total) are politicians, with another 17 percent being EU institutions. If we add to these the number of times that banks and financial institutions or their representatives appear in Eurocrisis-related articles, then the picture that emerges in online EU news coverage is one of elites, with very little space left for alternative voices to be heard (Table 3 ). The presence of national politicians and other state officials was even stronger in the enews reporting of the 2009 EP elections: two thirds of all actors reported (400 actors in total) in the main body of the coded articles as making an EU polity evaluation were national political actors.

Nevertheless, during the Eurocrisis period, particular EU institutions (ECB, Commission) have also gained significant visibility in EU-related threads, competing almost equally with national politicians for substantial online presence. The prominence of EU institutions in news media reporting is certainly related to events to a certain degree: it is hard to talk about the EFSF mechanism or the Greek 'bailout' without writing about the ECB. However, the data also suggest that the high visibility of certain categories of actors is also a matter of journalistic choice (Table 3). Journalists can choose to report the statement of specific individuals, which they believe are relevant in the context of EU politics or to which they have privileged access. Journalists can also choose to frame an actor's statement in a specific manner, e.g. giving credit to national political actors or criticizing and even degrading foreign or European actors. This becomes particularly clear from the 2009 EP elections' dataset. When it came to hosting statements made by specific public actors about the general principles underpinning the $\mathrm{EU}$, about the Union's current state of affairs or about the future of integration, journalists opted in most cases for statements made by national politicians. 
In the Eurocrisis dataset, technocratic and political elite actors (i.e. political actors in decision-making positions) dominated media coverage of the Eurocrisis in professional news platforms (Table 3 ) and their public statements hardly ever contained any critique or hint of doubt of their own actions. This combined with the seemingly 'neutral' crisis framing that news reporters adopt - namely, most frequently simply presenting the actions of various decision-makers as facts rather than providing commentary or analysis of those - leaves the technocratic hegemony discourse virtually unchallenged. Forty percent of the articles analysed (462 articles) presented the crisis and/or the specific crisis event in a neutral manner, i.e. without providing an evaluation of the reported actions or attributing responsibility to any actors.

Furthermore, only 374 of the analysed articles contained some type of analysis or commentary and when they did, the 'go-to' category of actors for providing analysis has largely been that of

Table 3. Public sphere actors present in online news/social media EU debates.

\begin{tabular}{lllll} 
Category of actors & $2010-2012$ & (Eurocrisis) & \multicolumn{2}{l}{2009 (EP elections) } \\
Citizens & 38 & $(1 \%)$ & 68 & $(17 \%)$ \\
EU institutions & 550 & $(17 \%)$ & 68 & $(17 \%)$ \\
Non-state/civil society & 102 & $(3 \%)$ & 14 & $(3 \%)$ \\
Journalist/News media & 307 & $(9 \%)$ & 47 & $(12 \%)$ \\
Bank/Financial institution & 887 & $(18 \%)$ & & \\
Political actors & 1610 & $(48 \%)$ & 196 & $(49 \%)$ \\
Other & 138 & $(4 \%)$ & 7 & $(2 \%)$ \\
Total & 3332 & $(100 \%)$ & 400 & $(100 \%)$ \\
EU: European Union & & & &
\end{tabular}

Source: The author.

economic technocrats. A technocratic regime of governance - and by extension, technocratic public discourse - usually pays only little attention to the problem of how the collective choices imposed by it can also be publicly justified. Technocrats do not usually argue but impose their choices as 'facts' or 'functional imperatives', unchallenged by journalists.

The importance of these repetitive framing patterns cannot be stressed enough. Repetition of news frames has been shown to have a formative impact on how audiences think of an issue (e.g. Berinsky and Kinder, 2006; Cappella and Jamieson, 1997; Lecheler and de Vreese, 2011). In one of the most thorough large-scale studies on media frames' effects, Sophie Lecheler and Claes de Vreese (2013) found that 
although exposure to repetitive frames does not systematically strengthen effects on opinion formation, if a frame is repeated with high frequency, then its effect on readers' views is stronger. In other words, there is a cumulative effect of repetitive frames, which depends on the frequency with which a news frame appears in the media. Crucially, cumulative repetitive framing influences not only news audiences with low levels of political knowledge but also politically informed audiences (Lecheler and de Vreese, 2011). By contrast, competitive news framing decreases the effects of news frames, as it exposes audiences to competing views. This does not mean, however, that when exposed to competitive news frames, individuals will always go for the rationally stronger argument. It is more likely that they will simply accept the frame that more closely matches their personal views or beliefs (Sniderman and Theriault, 2004).

Extrapolating from existing scholarly knowledge about the impact of news frames on opinion formation, we can therefore expect that the type of news frames used for EU news (a) will not be particularly conducive to readers' debating and (b) will have a strong effect on the way audiences think of the EU polity, regardless of individuals' knowledge about the EU because there is little framing variation across news media sources and across time. The quantitative (2009) and qualitative (2010-2012) analysis of readers' comments only partially confirms these two expectations, as is discussed in the following section.

\section{Euroscepticism (re)framed: the readers' perspective}

In the 2009 EP elections dataset, readers' commenting activity ranged widely from zero to 2492 comments per article, with an average of 112 comments per article. Numbers are similar for the 2010-2012 data, with commenting activity ranging widely across individual articles (range $=0$ to 2473 comments per article), across websites and across countries. While social media were not very widely or well-integrated in news sites back in 2009, within a year of the EP elections study concluding, all news sites had incorporated social media 'sharing' functions on their news pages, even in countries where journalists have been largely 'online media-sceptic', such as Greece (Michailidou, 2012). Readers' participation through Web 2.0 functions has thus dramatically increased during the Eurocrisis, particularly in Southern member states where internet availability and use was previously lagging behind the North-Western countries.

From a 'newsworthiness criteria' perspective (Boczkowski and Mitchelstein, 2012; Diakopoulos and Naaman, 2011; Weber, 2012 and 2013), the data presented here 
indicate that controversy, negative sentiment, proximity to and broad social relevance of the reported EU event, as well as a focus on politics, are the factors that override the 'surprise' quality of an event. Even something as unexpected as the Greek referendum could generate intense online debates about the EU polity among news readers. Indeed, the majority of commented-upon articles in the Eurocrisis study were about the 2011 Greek referendum event. Moreover, of the 60 top-commented-upon Eurocrisis threads (i.e. threads with more than 200 comments each), more than half were also about the 2011 Greek referendum.

With regard to the content of the online debates analysed, negative evaluations of the EU's institutional/constitutional set-up dominated across countries and at trans-EU level. Attributes such as 'the Brussels dictatorship', '(political) monster' and 'elitist government' regularly featured in the evaluations of the current EU polity set-up across countries. Negative evaluations prevailed irrespective of the source hosting the EU debate, as well as irrespective of the actor's position (i.e. acting in his/her capacity as journalist, citizen, politician or non-governmental organization (NGO) representative) and scope (national, transnational, foreign/non-EU). What this means is that there is no strong correlation between diffuse Euroscepticism and any of the abovementioned possible categories of actors. Readers, politicians and journalists are almost equally likely to criticize the EU in a diffuse manner.

This is a key unifying element of the EU online public spheres: a generalized, underspecified dissatisfaction or even disaffection with the EU polity. A far cry perhaps from a self-aware community, which consciously comes together in order to debate the current state of EU affairs and the future direction of European integration, the online news spheres examined here are nevertheless synchronized in terms of public sentiment.

The in-depth qualitative analysis of the top-commented-upon and shared Greek and German threads concerning the Eurocrisis sheds further light on how EU contestation and diffuse Euroscepticism in particular - unfold in readers' comments. Here, Euroscepticism is partly a reflection of the journalistic framing of the main article to which readers opt to respond. Eurosceptic journalistic inputs trigger off more intense online debates and the main critical tone of the article is amplified. The debate thus becomes progressively more homogenous in the sense that a pro-European voice is almost non-existent in reader commenting. 
Looking at the structure of Eurosceptic discourse in further detail, the critique of the EU polity invariably focuses on how Brussels is (becoming) a threat to: national culture and identity; popular self- determination; economic growth; and social security and well-being. Crucially, from a public legitimation perspective, the Eurocrisis has strengthened the view that the EU system is built on inequality of power and now also of access to resources. 'Brussels' is in this case seen as a neo-liberal market project that undermines international solidarity.

We can further observe homogeneity in the type of justification that underlies the polity evaluation: Democracy is the most frequently used category to contextualize or justify not only Eurosceptic comments but evaluations of the EU polity across the entire 'affirmative European to anti-European' spectrum. What unites the user community is its anti-elitism and self-understanding of constituting the people's voice that mobilizes in defence of the representative system of democracy or more frequently against its current corrupt, decaying version. The topics of discussion tend to drift from the immediate EU event that generated the thread such as the Greek referendum or EP elections campaign to more fundamental political or societal concerns, such as the state of democracy and questions of trust and solidarity both at national and EU level:

If the Greeks have the right to vote no, we also have the right not to pay. (Reader pkeszler, spiegel.de 2011)

\section{Discussion}

The findings on the profile of online news providers, actors, EU news frames and manner of online debating point to a seemingly contradictory development: there is uniformity in online media framing and discussion of EU politics, which however contributes to the deepening of existing conflicts between member states rather than the achievement of common understanding. The framing of EU politics is virtually confined to the national sphere, as is the scope of actors most visible in news reporting about the EU, even when a news item concerns events taking place in another EU country (Michailidou et al. 2014).

EU online news spheres are largely identical to the offline newspaper or television news environments, in terms of news frames, newsworthiness criteria and reporting style of EU events. What sets online news platforms apart from their offline counterparts - both TV and newspapers - is the amount of information they offer on 
key EU events. Links to their own archived material or to external sources make it possible for online news readers to either follow news stories back in time or to get several different perspectives on a story simultaneously. Apart from these information 'plus points', the community of news readers is still gathered around the same topics of relevance and exposed to a form of public opinion and will formation that feeds democracy in a national context. In this respect, the empirical findings presented here support previous scholarly findings about the Europeanization of offline news spheres (Koopmans and Statham, 2010; Liebert and Trenz, 2008; Wessler et al., 2008): nationally 'confined' news reporting survives online too. Not surprisingly then, politicians from the national political arenas are also the most visible actors in online news-making.

Nevertheless, three traits unify the EU online public space. Firstly, online news platforms reproduce rather than challenge the dominant frames of offline media. Secondly, readers' public exchanges are not necessarily dependent on the journalistic frames and style of reporting. Thirdly, disaffection with EU institutions is palpable in online debates of mainstream online news media. Euroscepticism, and in particular diffuse Euroscepticism as defined in this article, is no longer confined to the fringes of the online public sphere, or to specific public actors. Online public spheres in the EU fragmented by nationality - thus emerge unified through the reference to the same events/news items and the parallel use of the same frames and interpretations.

Reader-driven online EU contestation - polarized, emotionally charged, flaming but also frequently evoking democratic norms and European integration core values focuses on the legitimacy of governments, at national and European level. Both the EP elections and the Eurocrisis thus represent shared European experiences that are interpreted similarly across the European news space and that raise similar concerns among the people of Europe. Yet far from supporting ever more integration and European understanding, this development towards a unified public sphere highlights the limitations of transnational communication across borders and the accentuation of international conflict lines. The frames and themes used to report on EU politics events divide publics into 'us and them', perpetuating the national perspective along which the legitimacy and political value of the EU polity is assessed.

The competing dynamics of EU online contestation which these trends reveal need not be interpreted as a triumph of populist anti-EU rhetoric that signals the beginning of the end for the project of European integration. The manner in which Eurocrisis contestation unfolds and its content are essential factors for the public legitimation 
and success of attempted counter-crisis measures and reforms. Diffuse Euroscepticism and national frames may not bode well for the public legitimation of the EU polity and its institutions but are consistently present across time in all EU online news spheres examined here. Elaborate or crude, rational or emotive, the EU polity evaluations of online readers constitute a significant yet unpredictable element of the public legitimation process within which political actors and institutions operate, whether or not they choose to publicly respond to these comments. An alternative approach, therefore, is to see these trends as a necessary step in the process of the democratic normalization of EU politics, whereby no aspect of the EU political system can be considered as 'above contestation' if the EU project is to regain its democratic legitimacy.

\section{Acknowledgements}

This article draws on the extensive conceptual and empirical analysis of the EU online public sphere that my colleagues - Professor Hans Jörg Trenz, at the Department of Media, Cognition and Communication, University of Copenhagen and Dr Pieter de Wilde, at the WZB Social Science Centre Berlin - and I have conducted in the past six years. I am thankful to both of them for our lengthy and fruitful collaboration. My thanks also go to the two anonymous reviewers for their thoughtful comments and suggestions.

\section{Funding}

The research presented in this article was completed as part of the EUROTRANS and EURODIV projects, at the ARENA Centre for European Studies, University of Oslo. Both projects are funded by the Research Council of Norway.

\section{Notes}

1. See the Introduction of this Special Issue for the relevant debate; see also de Wilde and Zürn (2012); Statham and Trenz (2012).

2. The research presented in this article is a condensed version of the conceptual, analytical and empirical analysis of the EU online public sphere presented in de Wilde et al. (2013) and Michailidou et al. (2014).

3. For the 2009 EP elections project, which included news blogs as well as professional news websites, popularity of blogs was measured by visitor numbers and influence within the blogosphere, using blog aggregator popularity and influence lists, such as eBuzzing (2014; previously Wikio) and Technorati (2014a).

4. Mid-range tabloid media are popular and sensational but with substantially enough content, which attracts a higher-educated, more affluent readership than 'red-top' tabloids (McNair, 2009). 
5. The professional news websites selected for Greece in 2009 were not the three most popular, but ranked fourth, fifth and sixth. This is because the three professional news websites with the highest Alexa rankings at the time (Naftemporiki - a niche financial newspaper; Kathimerini - a quality center-right newspaper with very high circulation; and Eleftherotypia - another quality high-circulation newspaper of center-left ideology), did not offer any possibilities for user interaction, apart from email addresses to the editors. Eleftherotypia launched its interactive online platform (enet.gr) shortly after the 2009 project was concluded.

For the 2010-2012 project, we selected the websites most popular at the time of the three Eurocrisis events, rather than the most popular at the time of sampling (May 2013). In the period 2010-2012, Zougla.gr was the most popular, followed by Newsit.gr. The latter, however, proved highly problematic when trying to retrieve archived articles, so it was rejected in favour of Protothema.gr, which has been 3 rd most popular throughout the concerned period and similar in journalistic style to Newsit.gr.

6. The actual question of the referendum was never clarified, but when announced, the other EU leaders made it clear that any referendum would ultimately affect Greece's Eurozone membership regardless of how the question would be formulated.

7. To capture individual contributions to EU polity contestation, we operationalized the unit of analysis as a 'message', which is defined as one or more evaluations on European integration made by a single (collective) actor in a single time and space (de Wilde et al., 2013). For the 2009 EP elections study, Krippendorff's alpha was used to measure inter-coder reliability before, during and at the end of the coding period (eight coders involved). All variables had a score between 0.7 and higher, with the exception of the EU institutional set-up evaluation dimension, where the score was 0.62 . Although this is slightly below the usually recommended minimum measurement of alpha (0.667), it was accepted as valid and reliable score, as the actual coding practice was continuously discussed within the group providing for higher reliability than the formal test would lead to assume. For the Eurocrisis project, the overall inter-coder reliability achieved (seven coders, 16 datasets, 80 codes) was Fleiss' kappa $=0.66$ and for the actor codes (31 codes) Fleiss' kappa= 0.61 . Given the high number of codes, coders and articles involved, these kappa values were accepted as showing substantial agreement among coders.

8. This category was not present in the 2009 EP elections study.

\section{References}

Alexa Internet (2014) The top 500 sites in each country or territory. Alexa, the Web information company. Available at: http://www.alexa.com/topsites/countries.

Benz, Arthur (2013) An Asymmetric Two-Level Game: Parliaments in the Euro crisis. In Ben Crum and John Erik Fossum (eds) Practices of Inter-parliamentary Coordination in International Politics. Colchester: ECPR Press, 125-140.

Berinsky, Adam J and Donald R Kinde (2006) Making Sense of Issues Through Media Frames: Understanding the Kosovo crisis. The Journal of Politics 68: 640-656. 
Boczkowski, Pablo J and Mitchelstein Eugenia (2012) How Users Take Advantage of Different Forms of Interactivity on Online News Sites: Clicking, e-mailing, and commenting. Human Communication Research 38(1): 1-22.

Boltanski, Luc and Laurent Thévenot (2006) On Justification: Economies of Worth. Princeton: Princeton University Press.

Cappella, Joseph N and Kathleen Hall Jamieson (1997) Spiral of Cynicism: The Press and the Public Good. New York: Oxford University Press.

Crum, Ben and John Erik Fossum (eds) (2013) Practices of Inter-parliamentary Coordination in International Politics. Colchester: ECPR Press.

de Wilde, Pieter, Asimina Michailidou and Hans-Jörg Trenz (2014) Converging on Euroscepticism: Online polity contestation during European Parliament elections. European Journal of Political Research. doi: $\underline{10.1111 / 1475-6765.12050 .}$.

de Wilde, Pieter, Asimina Michailidou and Hans-Jörg Trenz (2013) Contesting Europe. Colchester: ECPR Press.

de Wilde, Pieter and Hans-Jörg Trenz (2012) Denouncing European Integration: Euroscepticism as polity contestation. European Journal of Social Theory 15(4): 537-554.

de Wilde, Pieter and Michael Zürn (2012) Can the Politicization of European Integration be Reversed? Journal of Common Market Studies 50(1): 137-153.

Diakopoulos, Nicholas and Mor Naaman (2011) Topicality, time, and sentiment in online news comments. 2011 Annual Conference (CHI) on Human Factors in Computing Systems, 7-12 May, Vancouver, Canada. Available at: http://www.nickdiakopoulos.com/wp-content/uploads/2007/05/copap final revised.pdf.

eBuzzing (2014) eBuzzing labs: Top blogs. Available at: http://labs.ebuzzing.com/top-blogs.

Fossum, John Erik and Agustín José Menéndez (eds) (2014) The European Union in Crises or the European Union as Crises? ARENA report 2/2014, Oslo: ARENA

Koopmans, Ruud and Paul Statham (eds) (2010) The Making of a European Public Sphere. Cambridge: Cambridge University Press.

Lecheler, Sophie and Claes H de Vreese (2013) What a Difference a Day Makes? The effects of repetitive and competitive news framing over time. Communication Research 40(2): 147-175.

Lecheler, Sophie and Claes H de Vreese (2011) Getting Real: The duration of framing effects. Journal of Communication 61(5): 959-983.

Liebert, Ulrike and Hans-Jörg Trenz (2008) Mass Media and Contested Meanings: EU Constitutional Politics after Popular Rejection. EUI RSCAS Report 2008/28, CADMUS EUI Research Repository. Available at: http://cadmus.eui.eu/handle/1814/9147. 
McNair, Brian (2009) News and Journalism in the UK. 5th edn. London: Routledge.

Michailidou, Asimina (2012) 'Second-order' Elections and Online Journalism: Comparison of the 2009 EP elections coverage in Greece, Sweden and the UK. Journalism Practice 6(3): 366-383.

Michailidou, Asimina, Hans-Jörg Trenz and Pieter de Wilde (2014) The Internet and European Integration. Opladen/ Berlin/ Toronto: Barbara Budrich.

Michailidou, Asimina and Hans-Jörg Trenz (2013) Mediatized Representative Politics in the European Union: Towards audience democracy? Journal of European Public Policy 20(2): 260-277, doi:

10.1080/13501763.2013.746126.

Peters, Jon Pierre B. and Tiina Randma-Liiv (2011) Global Financial crisis, public administration and governance: Do new problems require new solutions? Public Organization Review 11(1): 13-27.

Sniderman, Paul M and Sean M Theriault (2004) The Structure of Political Argument and the Logic of Issue Framing. In Willem E Saris and Paul M Sniderman (eds) Studies in Public Opinion. Princeton, NJ: Princeton University Press, 133-165.

spiegel.de (2011) Geplante Volksabstimmung: Griechischer Premier entsetzt Europa. 1 November, available at: http://www.spiegel.de/wirtschaft/soziales/geplante-volksabstimmunggriechischer-premierentsetzteuropa-a-795147.html.

Statham, Paul and Hans-Jörg Trenz (2014) Understanding the Mechanisms of EU Politicization: Lessons from the Eurozone crisis. Comparative European Politics. Advance online publication 3 March 2014, doi: 10.1057/cep.2013.30.

Statham, Paul and Han-Jörg Trenz (2012) The Politicisation of Europe. London: Routledge.

Technorati (2014) Politics blogs directory. Available at: http://technorati.com/blogs/directory/politics/.

Torreblanca, Jose Ignacio, Mark Leonard, Dimitar Bechev, et al. (2013) The continent-wide rise of Euroscepticism. Policy Memo 79, May, European Council on Foreign Relations. Available at: http://www.ecfr.eu/page/-/ECFR79_EUROSCEPTICISM_BRIEF_AW.pdf.

Usherwoood, Simon, Nicholas Startin and Simona Guerra (2014) New Dimensions in Euroscepticism and Opposition to the EU. Forthcoming: Edward Elgar.

Weber, Patrick (2012) Der Virtuelle Stammtisch. Determinanten interpersonal-öffentlicher Kommunikation auf Nachrichtenwebsites. In: Marlies Ockenfeld, Isabella Peters and Katrin Weller (eds) Social Media und Web Science. Frankfurt am Main: DGI, 457-459.

Weber, Patrick (2013) Nachrichtenfaktoren und Kommentierungsintensität von Online-Nachrichten. In Barbara Pfetsch, Janine Greyer and Joachim Trebbe (eds) MediaPolis - Kommunikation zwischen Boulevard und Parlament. Konstanz: UVK, 229-245.

Wessler, Hartmul, Bernhard Peters, Michael Brüggemann, et al. (eds) (2008) Transnationalization of Public Spheres. Basingstoke: Palgrave Macmillan. 


\section{Author biography}

Asimina Michailidou is a Senior Researcher in Political Communication at the ARENA Centre for European Studies, University of Oslo. Her work focuses on online media, audience participation and public communication strategies. 